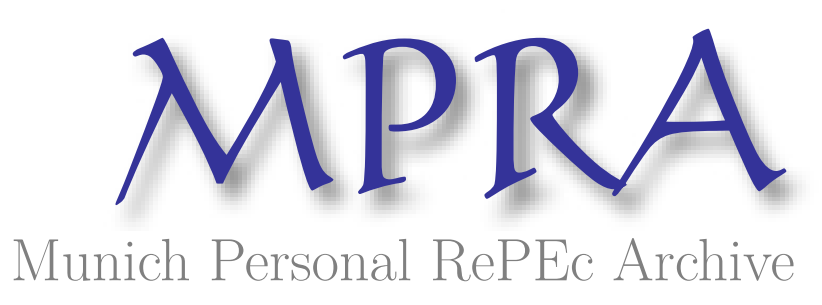

Governance of Innovation and Intermediation in Triple Helix Interactions

Todeva, Emanuela

BCNED

August 2013

Online at https://mpra.ub.uni-muenchen.de/67612/

MPRA Paper No. 67612, posted 14 Feb 2017 05:56 UTC 


\title{
Governance of Innovation and Intermediation in The Triple helix Interactions
}

\author{
Dr. Emanuela Todeva
}

\begin{abstract}
Research on sustainability and innovation-driven economic growth has exposed the lack of sufficient knowledge within the governance literature that can support and justify the extent of government involvement. This paper focuses on the governance of innovation and the intermediary role of the state. We synthesise the literature on governance and regulation and introduce the concept of intermediation in the innovation process. The paper employs the Triple Helix model that describes interactions and intermediation between government, industry and universities and extends this model by looking at the role played by intermediaries and among them public and private institutions, government bodies and independent organisations. We develop a new theoretical framework for the analysis of intermediation and governance of innovation and apply this to four case studies of intermediaries in the health technology cluster in the Greater South East region in the UK. Our empirical findings demonstrate the heuristics of the intermediation concept and the application of our Intermediation framework.
\end{abstract}

Key Words: Intermediation, Governance of Innovation, Triple Helix Interactions

\section{Introduction}

Intermediaries are recognised as actors that place themselves in the middle of relationships between other actors, or actors that facilitate the process of interacting in exchange relationships (Manzini and Mariotti, 2002). The literature confirms that intermediaries offer value-added services, such as: two-way communication and representation, facilitation in negotiations and decision making, support in public relations, or contract management for specific projects and programs - all of which reduce the individual search and bargaining Interactions. Industry and Higher Education, 27(4): 263-278. 
costs and increase the benefits for each participating organisation (Rubinstein and Wolinsky, 1987; Gehrig, 1993; Gu, 2003; Galeotti and Moraga-Gonzalez, 2009). Intermediaries in the context of National Innovation Systems (NISs) are known to create opportunities for matching funds to innovation capabilities, for meeting potential research partners, or for coordinating joint research projects and collaborations through management contracts (Agrawal, 2001; Yusuf, 2008). Intermediaries also assist in financing research and in investment in new products and technologies.

The concept of intermediation has been traditionally used by many disciplines, including finance and accounting, institutional economics, law and public administration theory, innovation theory and research on National Innovation Systems (NISs). Among the most investigated intermediaries in the finance literature are: banks, money, investment instruments, investment funds, contract agencies and different types of markets (spot markets, treasuries / derivatives / swap markets), or other financial institutions that take part in facilitating transactions and monetary exchanges. Intermediaries for institutional economists are organisations and institutions such as the Parliament, the Courts, the Law, or various formal codes of practice that influence the coordination of social interactions (Neudorf, 2009). For the legal practice and public administration theory, third parties as intermediaries carry both liabilities and power and control in regulation, arbitration and facilitating dispute resolutions (Wilson, 1987, Neudorf, 2009). It is not the state as such, but state institutions such as the Courts, the independent Judges, public authorities and other organisations and legal entities that carry out the regulatory, governance and intermediation function. Public administration theory has also referred to intermediation in the context of coordination and governance of complex and international scenarios and events, such as cross-border water and sanitation management projects, disaster management, or inter-government and inter-state operations Interactions. Industry and Higher Education, 27(4): 263-278. 
(Pearce, 2003). All these scientific discourses have evolved separately. They rarely share insights and in principle do not cross disciplinary boundaries. Each of the associated disciplines attributes different role to the state and articulates different conceptualisations of intermediating institutions and agents.

All these scientific disciplines, however, use the concepts of intermediation and facilitation as synonymous, confirming that the basic understanding of the intermediation function derives from the notion of third party facilitation. Third parties facilitate in communications, interactions, decisions, agreements, or in economic transactions and resource exchanges between different actors in multi-lateral relationships. Intermediation by third party agents and institutions exhibits both control and facilitation which are implemented through different activities, through coordination platforms and mechanisms.

The main aim of this paper is to bridge the disciplinary gaps between all these academic fields and to extend the scientific knowledge on intermediation. For this purpose we have reviewed a multi-disciplinary set of literature that looks into intermediation practices and governance of innovation in knowledge-based economies, where the public and the private sectors interact and the state intervenes in financing, regulation and governance of knowledge transfer. This literature points at the development of institutions and legislative governance framework for the financing of innovation, for the protection of intellectual property (IP), or for the knowledge management and knowledge and technology transfer (KTT).

We discuss the role of the state and its intermediation function in the context of Triple Helix (TH) Interactions with universities and industry. Our empirical observations on four distinctive types of intermediaries operating in the health technology sector in the South East

3 Todeva, E. (2013). Governance of Innovation and Intermediation in The Triple Helix Interactions. Industry and Higher Education, 27(4): 263-278. 
of England (UK) highlight their interactions across the TH and their involvement in the governance of innovation.

\section{The Governance of Innovation and Intermediation in the Triple Helix Relationships}

In the first section of the paper we examine the intermediation practices that apply to the governance of innovation in the university sector. We also look at what are the intermediation practices that support knowledge and technology transfer between the university and the industry. Governance and financing of research in universities traditionally involves distribution of resources from government bodies, appointment of agencies for monitoring and assessment of outputs, and establishment of rules for targeted resource allocation along with associated external supervision and control. Governance procedures involve the use of legitimate rules, contracts, relationship management practices, or other coordination mechanisms that oversee university performance and are exercised on behalf of the government.

Universities have been asked to lead in knowledge creation and simultaneously to provide knowledge solutions to industry and society as a whole through knowledge transfer and collaboration with other organisations. The questions of financing of the creation and transfer of knowledge and technology across the public and the private sector have challenged the existing governance practices.

The literature on financing innovation focuses on the balance between public and private sector contributions and the intense interactions and collaboration between the government, the industry and the university. The complexity of these interactions is captured by the TH Interactions. Industry and Higher Education, 27(4): 263-278. 
model, which has been developed to reflect on the dynamic university, industry, and government relations in the context of NIS. The TH model offers a new organizational and institutional paradigm for the analysis of the innovation process and the expansion of the role of knowledge and technology in the global socio-economic environment (Lissenburgh and Harding, 2000).

The original TH model induces evolutionary thinking in the economic and sociological notions of governance, innovation, interaction, facilitation and the transfer of knowledge among different agents ((Etzkowitz and Leyedesdorff, 1995; Leydesdorff, 2001). The TH literature has already recognised that the innovation process is dispersed, diffused and decentralised even when centralised funding from government is applied (Etzkowitz and Leyedesdorff, 1995; Cowan and Foray, 1997; Malerba, et.al, 1999; Kolfsten, 1999; Frenken, 2000; Leydesdorff, 2006; Robinson, et.al, 2007). It is dispersed across the public and the private sector, across universities, firms, research laboratories, private R\&D facilities, professional and scientific membership organisations and fragmented knowledge fields, pulled together in complex knowledge and technology application trajectories.

Coordination in this dispersed field is an essential element of the governance process, where third party agencies step in and research contracts are designed specifically to address coordination of resources and innovation outputs. Coordinating agencies are entrusted with management and supervision for R\&D projects, and as such, exercise both governance and facilitation function. Such coordination takes place across partnering research laboratories, across public and private sector establishments, across universities and industry, and even increasingly across national borders and national innovation systems. Complex interactions that emerge across the public and the private domain have been addressed by multiple Interactions. Industry and Higher Education, 27(4): 263-278. 
disciplines outside of the TH tradition (Roessner, 1993; Cohen, et.al, 2002; Monjon and Waelbroeck, 2003; Levy, et.al, 2009).

The development of the TH model, however, has largely ignored the institutional theory in economics and has been struggling to grasp the facilitation mechanisms. The model has failed to engage with, or to contribute to the literature on public-private partnerships (PPPs), or research that addresses the role for government as a creator of boundary-spanning mechanisms that facilitate academic-industry relations (Leydesdorff and Etzkowitz, 1998; Ohta, et.al, 2008). Such boundary spanning mechanisms bridge across the public and the private domains and facilitate interactions between commercial technology and reflexive and academic sciences, enabling university and industry to engage in a continuing flux, assuming tasks that before were largely the province of the other side (Leidersdorff, 2006).

The following section offers an extension to the current TH thinking and represents integration between the TH theory and the institutional governance theory that looks at facilitation and intermediation practices observed in the context of innovation and knowledge and technology transfer. Our extension to the TH model builds upon the current knowledge and explores more details on the bi-lateral links between novelty production within universities, wealth creation within industry and normative and political leadership within government (Fig. 1). We postulate that the governance of innovation requires the integration of the factors of production with the factors of innovation and the normative control, whereby bi-lateral and multi-lateral relationships in the $\mathrm{TH}$ are facilitated by intermediary institutions and agencies, appointed by governments to distribute resources and to assist and exercise supervision and control of the innovation process. Interactions. Industry and Higher Education, 27(4): 263-278. 
The complex system of heterogeneous TH actors (firms, public and private service providers, university centres of excellence in research and government departments) revolves around the participation of each actor in the innovation process that generates specific innovation outcomes, redistributed within the TH. In addition, the TH actors learn from each other, share information on product / process / technology innovation, transfer of knowledge and technology, or generate and acquire knowledge and technology externalities produced as byproducts of the innovation process (Fig. 1).

(Fig 1 about here)

In the original TH model the universities adopt a new entrepreneurial role that transcends beyond the previous academic mission of education and research. This new entrepreneurial role requires an active participation not only in the innovation and KTT process, but also in the associated with it market process (economic impact of new technology) and political process (allocation and use of public funds for innovation). Our model on Fig. 1 makes this level of interaction and interpretation explicit, whereby successful commercialisation of university technologies is seen as meeting wider social and political objectives and performance targets pursued by industry, by governments and by other stakeholders. The innovation process takes place simultaneously with the market process of product/technology development and commercialisation and with the political process of regulation, resource allocation, accountability and control.

Although the TH literature has accepted the recursive iteration between the helices, there is still the assumption that the state plays a special regulatory role that dominates the $\mathrm{TH}$ relationships. This regulatory function of government arises out of the need to facilitate between commercial and academic establishments in the KTT process and the inability of the universities or the industry to take leadership. The leading intermediary role of government Interactions. Industry and Higher Education, 27(4): 263-278. 
also arises out of its role as representative and guardian of the public interest and regulator of the resource allocation in the economy, providing also legal protection of IP rights. The public administrator function of government does hold a superior role in the TH model even though this is sometimes obscured by the assumptions of recursive feedback loops in the TH interactions.

A number of empirical questions emerge from this discussion regarding the intermediation process: 1) How does the state participate in TH interactions, i.e. establishing and managing relationships with industry and the university sector; 2) How does the state perform its role as a facilitator and regulator in the KTT process; 3) How does the industry engage with public organisations that deliver research and education; 4) How do universities engage with different sources of finance for their activities and how they interact with commercial enterprises. Innovation theory has partially contributed to these questions with discussions on government innovation policies, modes of financing of innovation, or the institutional practices and channels for transfer of knowledge and technology. Regulatory interventions that change the environment for universities and industry, and that distribute incentives and constraints in the system, are a form of facilitation that stir the innovation process in a

particular direction. In the subsequent sections we will discuss some leading contributions in the literature that explain a variety of intermediation and KTT practices that have emerged for the governance of innovation.

\section{Intermediation Activities, Practices and Channels that Facilitate the Governance of}

\section{Innovation} Interactions. Industry and Higher Education, 27(4): 263-278. 
There are a number of examples of intermediation activities and practices employed during the innovation process and the transfer of knowledge and technology across the public and the private sector. Specific examples of these intermediation activities are: searching for partners, matching complementary assets and technologies, bridging and translation of knowledge across different theoretical disciplines, decision support, protection of IP rights, evaluation of science and technology outputs, as well as financing and legal protection of contracts and agreements (Argote and Ingram, 2000; Levy, et.al, 2009). These are conducted under the umbrella of regulation, specific policies, contact management, relationship management within a specific channel for transfer of knowledge and technology (Fig. 2).

(Fig 2 about here)

In the following sections we will discuss each group of these intermediation activities and their governance impact.

\section{- Intermediation and Governance through Regulation and Legitimate Rules}

The regulation theory offers insights into the activities of regulatory agents for the enactment of justice and the exercise of legal supervision (Bendor, 1990, Cannon, 1994, Parkinson, 1994, Russell and Waste, 1998, Todeva, 2005, Lee and Liu, 2008, ). The theory promotes the idea that regulation involves a legitimate government that has authority and power, as well as the capacity and capabilities to generate rules that govern economic behaviour within a socioeconomic system (Todeva, 2010). Regulation via rules and laws is seen as an effective governance and coordination of behaviour of economic actors. The rules and the laws are facilitating mechanisms enabling governments to distribute incentives and sanctions across the entire system of economic actors and to exercise its regulatory role. The organisations and agencies that design and implement these rules and laws, or that enforce them and monitor compliance in behaviour - all these organisations, institutions and government bodies are Interactions. Industry and Higher Education, 27(4): 263-278. 
effective intermediaries that facilitate the co-alignment of interests on a large societal scale. The legitimacy of the regulatory institutions, and the rules of law themselves are essential steps towards effective intermediation. The creation and legitimation of legal and law enforcement institutions by government is an active process to create a regulatory environment that stimulates and supports innovation. The Courts and the Police can be described as effective intermediaries and regulatory establishments.

Essential part of the governance and regulation of innovation is the creation and legitimation of funding bodies and funding mechanisms, where we see governments developing their role to intermediate and oversee the innovation process through resource allocation, supervision and control. The same devolution of responsibilities is observed for the standardisation of technology outputs and the regulation of intellectual property (IP). The regulation and governance of the innovation process on behalf of the government is undertaken not only by public bodies, but increasingly by professional organisations, industry associations, and other private or not-for-profit formations and membership organisations that constitute and represent public interests - all established with the purpose to finance and oversee aspects of the innovation process.

The governance and regulation of innovation involves a combination of internal self-control and external control, which enable interacting parties to reach and implement agreements about resource exchanges and payments, about information sharing and assistance, about distribution of costs and benefits, or to engage in co-development and value co-creation.

- Intermediation and Governance Through Innovation and Technology Policies Interactions. Industry and Higher Education, 27(4): 263-278. 
Governments use both regulatory interventions (passing laws through Parliament) and policy implementation activities (distribution of resources according to political objectives). One of the main innovation and technology policy areas consists of policies that provide incentives to invest in future technological capabilities. Among these policies are: mission policies, infrastructure policies, diffusion and technology transfer policies, and developing technological districts and clusters (Dodgson and Bessant, 1996, Justman and Teubal, 1996, Narin, et.al, 1997, Robinson, et.al, 2007, Bramwell and Wolfe, 2008). Governments use facilitation and intermediation in all of these policy areas both at the stage of policy design and at the implementation stage. Policy design involves both internal government departments and external political organisations or independent institutions that facilitate the dialog with the public. Policy implementation always involves multiple agencies and interactions and relationships between these organisations require facilitation platforms, such as meetings and conferences, or brokers and intermediary agents, appointed to assist communication and decision making. Policy implementation is often undertaken by external organisations and intermediaries that act on behalf of the government, being funded by it.

Mission policies consist of setting priority targets for industry and technology areas and offering financial support (grants and funds) for research into cutting edge technologies, carried out by public research institutes, or by firms. The principal objectives of these policy initiatives are to concentrate state financial resources on research in new technology areas at a pre-competitive level. Governments use different intermediaries to set innovation priorities and to distribute funds to selected technologies where the process is often managed and controlled by the intermediaries in close relationship with government departments. An example of such an institutional framework is the work of the Technology Strategy Board (TSB) in the UK, established to assist the government with setting priorities new technology Interactions. Industry and Higher Education, 27(4): 263-278. 
fields. TSB distributes financial resources to industry for innovation and technology development and facilitates the KTT process across the university and the industry sectors.

Although mission policies emerge under the political leadership of government, they rest upon existing technological capabilities in the industry sector and the knowledge capabilities within the university sector. Consequently, both the design and the implementation of mission policies require interactions within the $\mathrm{TH}$ and translation of information across different domains within the Triple Helix. Intermediation practices that assist in the design and implementation of mission policies include analysis of competitiveness targets at national and industry level and translation of technological capabilities into investment targets.

Infrastructure policies have been flagged out in the literature on innovation as central for the development of NISs. They exhibit direct investment of public funds in technical infrastructure for universities and industry, or building technological capabilities in the university sector and making them available to industry (Justman and Teubal, 1996). The implementation of infrastructure policies involves intermediation that assist government in needs analysis, feasibility studies, or stakeholder engagement.

Diffusion and technology transfer policies are the most traditional initiatives by governments in support for the innovation process. They involve capital grants to public sector research establishments through subsidies for the purchase of new machinery and research equipment, or funding of collaborative projects. Most recently these have been directed towards the industry, where it has been recognised that the transfer of knowledge to small and medium size firms has not been very effective due to the capability gap that prevents smaller companies from making use of external know-how coming from the universities (Dodgson Interactions. Industry and Higher Education, 27(4): 263-278. 
and Bessant, 1996). Part of the diffusion and technology transfer in industry has become the promotion of collaborative research between universities and small firms, or the assistance in the creation of new technology firms as spin-offs from universities. The role of intermediaries in this case has been to solicit both the recipients of grants (firms, universities, science labs) and the government agencies that implement diffusion, technology transfer and other science and technology policies (Narin, et.al, 1997, Zucker, et.al, 2002).

Another recent government line of support for innovation has been the development of technological districts and clusters. These government policy initiatives involve investment of public funds in collaboration with private sector investors in building research parks and innovation hubs to co-locate technology firms, and to stimulate regional economic growth. The main target, identified for these initiatives, is the support for technology-based small and medium size firms (SMEs) through funding the co-location of firms, their networking, as well as explicit R\&D activities. The formation of regional clusters and technology networks between private and public bodies, firms and universities, has been the main way to stimulate innovation in SMEs, to support regional growth, and to extend the dissemination of R\&D outputs (Antonelli, 1999).

All government policies described above resemble governance practices that involve allocation of public resources for innovation, and the exercise of the regulatory function of the state through distribution of incentives, designed to affect the innovation behaviour of public and private sector organisations. The implementation of innovation policies requires vast facilitation, collaboration and coordination, involving a variety of intermediary actors that assist with various value-added services. These are services for the setting of innovation targets and technology priorities, for the facilitation of knowledge-creation for the finance of 
$\mathrm{R} \& \mathrm{D}$ and the implementation of knowledge and technology transfer, for the diffusion and commercialisation of research outputs. The recipients of these services are government procurement departments, the producers of innovation (universities, firms and research laboratories), or the collective users of innovation - commercial establishments, consumer market organizations, industrial associations and chambers of commerce, research labs that require knowledge and technology intensive inputs.

\section{- Intermediation and Governance through Contract Management}

Repetitive and long-term transactions between firms are based on formal contracts and agreements between them that govern their relationships, protect their rights and regulate payments and resource exchanges. These inter-organisational contracts are governance forms that safeguard specific assets and value-distribution arrangements between firms (Haugland 1999).

Contracts are extensively used in the $\mathrm{TH}$ interactions to specify each agency rights and responsibilities and to govern resource flows, payments and liabilities. Contracts as governance mechanisms create a neutral body / agency with authority to control specific issues related to the implementation and operational procedures within inter-organisational relationships and exchanges. Management of contract involves the exercise of authority by specialised internal administrative departments or external intermediating agents, such as representatives of management service organisations.

Contract management is used in all R\&D projects, technology partnership agreements, licences, or know-how transfer arrangements, where intensive sharing of knowledge, technology and know-how are critical prerequisites for success, and contracts serve an Interactions. Industry and Higher Education, 27(4): 263-278. 
intermediary function for co-alignment of interests, coordination and cooperation in multilateral and multi-agency settings, which are typical for all stages of the innovation process.

\section{- Intermediation and Governance through Relationship Management and}

\section{Representation}

Governance involves not only control and coordination of resource flows, but also facilitation of relationships and activities, or enabling actors to utilise resources and to achieve innovation and performance targets. Facilitation and relationship management are essential intermediation and governance activities that affect the efficient allocation of resources and the mediation of risk in innovation.

While formal contracts represent legally binding agreements, relational contracting embraces unspecifiable terms and conditions in complex and open-ended scenarios, as well as collective inter-organisational strategies for eliminating rivalry through tacit coordination, optimisation, and collaboration. The intermediation is embodied both in the terms and conditions of the formal contract and in their managed implementation. Relational contracts are associated with relational coordination mechanisms such as reciprocity norms, inter-organisational trust, and social capital (Borsch 1994).

Fligstein and Freeland (1995) identify a number of internal and external relationships that address governance problems at organisational level and require intermediation. First, these are the relationships between management and workers that deliver efficient employment of resources and factors of production. Managing employment relationships requires an active intermediation in terms of translating resource inputs into innovation targets, then into 
structure and distribution of payments, and among the most well-known intermediaries are labour unions and consultative boards and agencies.

Second, these are the relationships between management and shareholders, or relationships with sponsors, funding bodies, investors and capital markets, where information asymmetries require facilitated communication between owners and managers. Examples of intermediation with strong governance impact are shareholder meetings, or participation of outsider directors in governing institutions.

Third, these are intra-organisational relationships that derive from the division of labour and the distribution of power and responsibilities within organisations. Intermediation and facilitation at operational and strategic level is undertaken by established organisational structures for effective decision making, or internal collective bodies with authority.

Fourth, this is management of relationships with suppliers which secure effective control of inputs. Technology intensive operations require high value-added inputs, where good supplier relationships offer guarantees against operational risks. Intermediaries, carrying the governing authority to select suppliers are contracted for that purpose.

Fifth, these are relationships with competitors that create opportunity for risk-sharing in collaborative R\&D. Alliance contracts intermediate such contracts.

Finally, relationships with governments, public institutions and other stakeholders also require effective management as they facilitate the enhancement of legitimacy and reputation of firms Interactions. Industry and Higher Education, 27(4): 263-278. 
and generate direct reputation effects. These relationships are facilitated through stakeholder associations, public relationship activities, marketing and media coverage.

Both relationship management and contract management represent intermediation practices that affect the allocation of resources and coordination of activities and rely on explicit coordination rules and regulation. Contract management and relationship management in R\&D both facilitate knowledge and resource sharing which brings a positive effect on the cost and revenue streams of innovation establishments, supporting the creativity and the innovation process.

\section{- Intermediation and Governance Through Channels for Knowledge and Technology}

\section{Transfer (KTT Channels)}

The literature on innovation and KTT has described a number of established channels that capture specific intermediation practices and governance forms. These channels prescribe the legal framework for the exploitation of resources throughout the innovation process, for the transfer of know-how, the transfer of rights over innovation outputs, and the regulation of claims over commercialisation of knowledge and technology (Fig. 3). KTT channels regulate the allocation of $R \& D$ resources and the coordination of behaviour across innovation actors.

Among the studied KTT channels are: patents registration, technology licensing, R\&D alliances and joint ventures, R\&D outsourcing, companies' spin-offs, scientific publications, citations and co-authorship. KTT channels are designed and regulated by government agencies (patent offices, licensing and contract enforcement establishments, ranking and certification agencies). IP protection legislation is critical in shaping the specific institutional forms. Some of the KTT channels are actively supervised by independent professional and Interactions. Industry and Higher Education, 27(4): 263-278. 
commercial organisations (for example, publication rating agencies), and scrutinised by the government, by the media, or by other public organisations. The governance of KTT channels, hence, is distributed across the public and the private space outside of the university and the industry sector.

All channels of knowledge and technology transfer, outlined in Fig. 3, involve different forms of governance, established to regulate relationships, activities, resource allocation and exchanges, including a variety of combinations across market coordination (using armslength contracts and contract-protection laws), hierarchical coordination (bureaucratic decision making and administrative control), network coordination (platform-based coordination mechanisms that include sharing of resources and benefits), community coordination (ethical co-ordination via professional associations and voluntary membership organisations), cooperative coordination (through partnerships between autonomous organisations committed to sharing of resources and benefits), or political coordination (via collective membership organisations and alliance type of establishments that allocate resources according to political objectives) (Levacic, 1991; Todeva, 1998; Todeva, 2005; Robinson, et.al, 2007; Todeva, 2010).

(Fig 3 about here)

Patents enable firms to exploit invention developed by academic researchers (university), or R\&D outputs from another commercial entity (industry) (Agrawal and Henderson, 2002; Hellman, 2005). Both the patent registration and the patent expropriation require specialised procedural and expert knowledge that is located outside the research domain and involves a fee bearing service from a third party intermediary organisation. Contract relationships with these service firms, professional consulting organisations and specialised legal entities are common intermediaries. Patent protection is regulated by country-specific legislative Interactions. Industry and Higher Education, 27(4): 263-278. 
frameworks that govern a complex system for transfer of tacit and expert knowledge.

Patenting represents a complex governance activity that involves a specific regulatory form of registration and of protection of rights and professional type of knowledge certification.

Knowledge and technology licensing is another governance practice, which involves intermediaries such as technology transfer offices (TTOs) and technology licensing offices (TLOs) within universities, or other specialised administrative departments that manage licensing contracts (Siegel et al., 2003). TTOs and TLOs as specialised intermediaries develop and manage complex sets of relationships and intermediate between the scientists and inventors, the funding bodies and financial institutions that allocate resources for $R \& D$, and the firms that exploit innovation outputs from universities.

Contract research at universities represents research commissioned by the industry and refers to scientists' interactions with the private sector for funding and sponsorship for their research and innovation, or tenure status (Mirowski and Van Horn, 2005). This channel for knowledge transfer is perhaps the most direct form of interaction between the university and the industry sector, regulated by legally protected private contracts. Resource exchanges and interactions are governed by financial and technical specifications in contracts negotiated by the parties. The legal and other service intermediaries assist in the search for contractors and enable contracting parties to reach and implement their agreements. Contract research can be intermediated by specialised knowledge brokers with knowledge in a particular technological field, or by generalist intermediaries offering legal and business services.

Collaborative research differs from contract research as it involves design and execution of $R \& D$ projects jointly by the industry and university/science institutions, either on a bi-lateral Interactions. Industry and Higher Education, 27(4): 263-278. 
or a multilateral consortium basis. It is intermediated in a similar way by contracts, specialised administrative departments in universities, or generalist legal protection agencies (Meyer-Krahmer and Schomoch, 1998; Zucker et al., 2002). The main intermediaries that govern and facilitate collaborative research are financial institutions and funding bodies. They allocate resources to individual partners and projects. The governance issues that emerge in collaborative research are: accountability for time and resources spent and control over the redistribution of profits and rents from the commercialisation of knowledge and technology. The essence of $R \& D$ collaborations is in managing resource flows that run across organisational boundaries. Classical concepts such as ownership, governance and control become very ineffective tools for coordination and control in collaborative research projects (Monjon and Waelbroeck, 2003).

Scientific publications are a major channel for knowledge transfer used both by researchers from the academia and from the industry. Industries consider codified output, such as publications, as the most important form for acquiring and protecting knowledge, as academic publications, co-authored papers and reports account for more than $73 \%$ of the citations in the US industry patents (Narin, et al, 1997; Cohen, et al, 2002). The intermediaries in this process are specialised scientific journals, editorial boards, publishers and knowledge depositories. Ranking agencies in particular exercise a governing function as they produce reputation effects which have further impact on financing research and commercialisation of innovation outputs.

The separation between authorship rights for individual academics and ownership writes over published work for universities and publishers involves additional governance mechanisms 
that influence the codification and dissemination of knowledge, or the distribution of reputation rents (for the authors) and profits or royalties (for the publishers and universities).

Co-operation in graduate education is a form of knowledge transfer that involves advanced training for enterprise staff and exchanges of research staff (such as $\mathrm{PhD}$ students). Authors have argued that the employment of university researchers in industry and sponsored $\mathrm{PhD}$ programs are effective way to transfer knowledge from university to industry, especially in technological and knowledge intensive sectors (Meyer-Krahmer and Schomoch, 1998; Zucker, et al., 2002; Gubeli and Doloreux, 2005). Schartinger, et al. (2002) confirm also that the mobility of human capital, both via employment of $\mathrm{PhD}$ graduates and via co-supervision of $\mathrm{PhDs}$ is among the most frequent and most beneficial form for knowledge transfer. Other examples of cooperation in graduate education are student placements and exchanges, or internships that have an impact on university curriculum and at the same time allow firms to tap into the latest thinking in university research labs (Argote and Ingram, 2000). The governance for such interactions rests mainly with the funding arrangements for specific transfer schemes, where funding institutions design contracts and terms and conditions for the financial support and the intellectual property rights.

The founding of spin-off companies from universities represents a form of knowledge transfer which leads to major innovation in the economy, where technology-oriented firms employ researchers from the science-base. The establishment of spin-off companies is facilitated by a large number of internal and external service organisations, legal firms, and financial institutions, whereby different governance issues are addressed at different stages of the process. Spin-off companies use intermediation by specialised brokers that evaluate the market potential for the innovation outputs, or the technology and management capabilities of Interactions. Industry and Higher Education, 27(4): 263-278. 
the spin-off firms. The process is almost unique for each event of a spin-off company, hence, the governance arrangements are unique too.

Knowledge transfer within the triple helix can occur also as part of un-governed and unsupervised informal relationships. A series of informal relationships between industry and university can emerge during exhibitions, meetings, conferences and demonstration events in which researchers, managers and boundary-spanning agents can meet together, or exchange knowledge and form relationships. Science exhibitions are the principal forms through which new knowledge enters the commercial domain (Shane, 2002; Zucker et al., 2002). Event organisers are the main intermediaries that fulfil the brokerage role of bringing creators and potential users of knowledge and technology together.

\section{Empirical Observations of the Triple Helix Intermediation Practices}

Our empirical observations of four cases of intermediaries in the health technology sector (HTS) in the Greater South East of England (UK) demonstrate different institutional forms that engage in KTT. These cases reveal the complexity of interactions and intermediation practices employed within the TH to affect aspects of the innovation process.

The HTS in the Greater South East encompasses over 4700 core technology firms and around 11400 supply and delivery companies (representing the industry), 51 National Health Service [NHS] Trusts (as a target market), and over 60 research active universities and other public sector research organisations that generate outputs in biotechnology, pharmaceutical, surgical/medical instruments and devices, diagnostic and medical research (Todeva, 2008). The geographic boundaries of the cluster encompass an intersection of South East of England, Interactions. Industry and Higher Education, 27(4): 263-278. 
East of England and Greater London. Although there is strong regional dynamics, the cluster is actively connected to the wider UK environment, as well as globally.

The financing of innovation in this cluster is undertaken by nation-wide funding bodies, among which the Department of Health financing NHS as recipients of innovation outputs, The Technology Strategy Board (TSB) financing major research platforms to support the industry, and a number of major Charities and national funding bodies such as: Wellcome Trust, the Medical Research Council [MRC], the Biotechnology and Biological Sciences Research Council [BBSRC[, the Engineering and Physical Science Research Council [EPSRC], among others (Todeva, 2008). These intermediaries have created funding programs governing the innovation process in specific technology fields and using a large number of consulting organisations and specialised service providers with knowledge and capabilities in cutting edge technology areas of life science and bio-medical research (Todeva, 2008).

Our four selected cases that are active in the region are: a nation-wide funding body (Technology Strategy Board - TSB), a venture capital firm with national and global reach (IPSO Ventures), a technology transfer organisation (ISIS), and a membership organisation (South East Health Technology Alliance - SEHTA). Data was collected using structured interviews and document analysis. The results from the investigation are summarised in Table 1.

As outlined in Table 1, the four investigated intermediaries are substantially different even when they apply similar strategic approach. Each of them represents a unique bundle of skills and capabilities that serve specific interests of various shareholders and stakeholders. All of the investigated intermediaries facilitate interactions between the public and the private sector Interactions. Industry and Higher Education, 27(4): 263-278. 
and all of them support the innovation process employing a variety of facilitation tools such as meetings, events, relationships management and assistance for collaborative research, project development and access to funding for R\&D.

Table 1 about here

SEHTA and TSB are both focused on business support for the industry, organizing meetings and events, during which they promote grants and network creation, where managers and academics can come into contact and forge relationships. Both of them inform managers and academics regarding funding opportunities. However, TSB allocates funds, while SEHTA assists in project design and participates in projects by exploiting their network of contacts and membership base. The strategic orientation of SEHTA and TSB is to address the needs of the industry, while the strategic efforts of IPSO and ISIS are directed towards identifying business opportunities related to commercialisation of university technologies.

There is only one intermediary in our selection that is fully focused on market-pull strategy IPSO Ventures. As such, their activities are set to achieve specific commercial targets. The technology transfer office ISIS differentiates from this by adopting a balanced approach between market-pull and technology-promotion strategy. ISIS and IPSO intermediation is also focused both on interaction with industry partners and with scientists from universities.

IPSO is the only intermediary that reports undertaking a thorough market research and market analysis, taking into consideration statistical trends, using business reports, databases and other consulting. TSB and SEHTA very much rely on building individual capacity for understanding business needs, All intermediaries learn about the market using reports, personal relationships with funding bodies and investors, and using its human capital, i.e. employing people who have scientific background and industry experience, who have Interactions. Industry and Higher Education, 27(4): 263-278. 
contacts and know about what is going on in industries and university establishments. All four intermediaries employ informal relationships, as well as building and managing networks as part of their facilitation activities.

Finally, the observations presented in Table 1underline that none of the intermediaries are involved directly in any kind of scientific knowledge transfer. Their main contribution to the innovation and the knowledge transfer process is to finance directly (TSB, IPSO); to offer supplementary financial support (IPSO, ISIS); to assist in obtaining finance (SEHTA); to facilitate close relationships with funding bodies (TSB, SEHTA, ISIS); to facilitate close relationships with private investors (IPSO, ISIS); to manage close relationships with DoH and NHS organisations (TSB, SEHTA, ISIS); to manage close relationships with the industry (TSB, SEHTA, IPSO); to facilitate industry-university interactions through meetings and events (TSB, SEHTA); to match partners from university and industry (IPSO, ISIS); to manage contracts between university and industry (TSB, ISIS); to manage patent/licensing activities and the creating of spin-out companies (IPSO, ISIS); to manage consultancy services (SEHTA, ISIS); managing university-industry cooperation in education (TSB).

Three of the interviewed intermediaries address governance issues related to asset ownership, IP ownership and contract management (TSB, IPSO and ISIS). These intermediaries have undertaken governance responsibilities by the virtue of their establishment. The TSB was established by the UK government to govern the investment of public resources to priority technology sectors in the UK economy and to stir the innovation process at the intersection between the industry and the university. IPSO was established by its founders to invest its own capital to new technology firms through spin-offs from the university sector. ISIS was established to manage IP and spin-off companies on behalf of the University of Oxford. All Interactions. Industry and Higher Education, 27(4): 263-278. 
these intermediaries exercise different types of supervision and control in the innovation process through managing contracts and finance from different sources. Overall all interviewed organisations use a different blend of governance and coordination mechanisms to exercise control and to facilitate TH interactions.

\section{Discussion on Triple Helix Governance and Intermediation for Innovation}

Innovation takes place both in the public sector (universities) and in the private sector (industry). The competitiveness and performance of firms however, is increasingly dependent on successful R\&D collaboration and knowledge sharing with universities. The effective transfer of innovation outputs across public and private sector organisations is critical for governments, for university and for industry. Innovation at firm level is often associated with industry absorption and commercialisation of knowledge and technology generated by universities and other public sector research establishments. Technology is transferred through $\mathrm{PhD}$ graduates, through collaborative contract research, or licensing activities. The governance of innovation and KTT, hence, is a key component in economic development platforms, where the effective interactions between regulatory government bodies, the industry and universities are critical. These new trilateral relationships are characterized by complexity of interactions, interdependencies, and intensive flow of knowledge and resources between public and private actors.

One of the most fundamental aspects of TH interactions in innovation systems is the integration of the factors of production, factors of innovation, and factors of normative control through dynamic relationships between government, industry and university. This is facilitated by intermediaries, such as banks or funding bodies, legal institutions and 
administrative agencies that govern the strategic choices for allocation of resources and distribution of rents from innovation outputs. Such intermediaries mitigate the risks from the uncertainties associated with commercialisation of research outputs, or the risks for return on investment in R\&D. They also protect the ownership rights of inventors and holders of patents and licenses. Providers of funds bring additional facilitation services in the form of managerial know-how, contacts, troubleshooting skills or risk assessment skills (Hellman and Puri, 2002).

Our theoretical model of Triple Helix Intermediation (Fig. 1.) promotes the idea that the locus of innovation is to be found in facilitated networks and partnerships and not in individual firms, or isolated university labs. Intermediaries emerge to provide specialised knowledge, finance and services that individual entities either cannot provide by themselves, due to a lack of capabilities, or are unwilling to provide, because of economic costs. Intermediaries participate in the formation of innovation networks and facilitate the search for partners, contract negotiations and smooth interactions at the stage of transfer of knowledge and technology between organisations. The facilitation by intermediaries in KTT activities that involves financing, legal protection, and other services, requires absorptive capacity in individual organisations, to absorb the value-added from intermediation and from the interaction with collaborative partners. Often intermediaries assist with enhancement of this absorptive capacity.

The Triple Helix Intermediation model (Fig. 1.) focuses on the knowledge infrastructure of overlapping institutional spheres, with each institution taking the role of the other and with hybrid organizations emerging at the interface in order to facilitate the interactions and exchanges and to regulate the resource flows. Universities in the Triple Helix system play Interactions. Industry and Higher Education, 27(4): 263-278. 
entrepreneurial roles and undertake marketing of innovation, create company spin-offs, and engage in licensing and registration of patents, while firms move closer to universities, hosting academic initiatives, sharing knowledge, engaging in collaborative projects with universities, involving managers in university's activities, and co-training university's graduates. Finally, government becomes investor in knowledge and technology and more engaged in developing innovation capabilities in universities and the private technology sector as a broker for technology collaboration, for innovation, creativity and knowledge and technology transfer. All three institutional domains develop specialised service departments, or subcontract such services to assist in innovation management.

In the development of our Triple Helix Intermediation model, we have put emphasis on four additional aspects. First, this is the dynamics in the Triple Helix interactions which stems from even deeper interaction and overlap between the market process of competition and competitiveness, the political process of using political objectives for resource allocation, and the innovation process that involves invention, creativity and exploitation of new knowledge and technology (indicated on Fig. 1. by the small spheres inside the Triple Helices). The outcomes from the simultaneous enactment of these processes result in complex motivations and complex behavioural orientations of all actors towards novelty production, wealth creation and regulation and control of innovation.

Second, this is the interpretation of the three helixes in terms of factors of production (industry), factors of innovation (university), and factors of normative control and regulatory activity (government). Economic growth and sustainable development require utilisation of all three factors, where factors of production change under the influence of factors of innovation, factors of innovation are enabled by the factors of production. Factors of Interactions. Industry and Higher Education, 27(4): 263-278. 
normative control are employed for the management of both factors of innovation and factors of production (including capital, labour, resources, technology and entrepreneurship). The simultaneous mobilisation of factors of innovation, factors of production and factors of normative control require intermediation at a meta-level of government agencies and government approved private and public sector third parties.

Third, the dynamics of the Helices generate innovation outcomes (innovation product and process, or knowledge and technology transfer) which are 'public goods' that represent value added with both social impact and commercial benefits. The redistribution of these benefits requires and involves further cycles of interactions across the Helices under the governance and intermediation by a complex system of organisations engaged in IP registration and protection.

Finally, in our extension to the Triple Helix model, we focus on the role of intermediaries, or these agents and practices that add value by helping university, industry and government to perform their role. Financial and institutional intermediaries enable the integration of the innovation process across the public and the private domains, across different science and knowledge fields, and across different stages of the research process. The intermediation involves not only intermediary agents, but also different intermediation practices, where intermediaries translate the message from one helix to another, while helping them to engage in coordination of resources and activities across each other. Overall the model induces assertions about complex and indirect influences between multiple agents, representing heterogeneous types of institutional formations, which require multi-layered governance structure and intermediation for their interactions. 
Different intermediation practices are suitable for different stages of the innovation process. Prescriptive rules and regulations on managing such a process are unlikely to have a positive impact. The role of government, hence, is evolving around un-prescribed roles of risky allocation of resources and the implementation of a variety of policies that require new mechanisms for regulation, control, supervision and coordination. Such dynamic and complex regulatory presence can be described as 'open regulation' that enables co-evolving behaviour of the industry-university-government actors. This paper marks the foundation arguments on open regulation and highlights the need for future research in the field.

\section{Conclusions}

Services from intermediaries are actively employed where there is a weakness within the $\mathrm{TH}$ communications and interactions. Weaknesses in communications between universities, industries and the health care system in the UK cause a high number of innovation and technologies to be left undeveloped and dormant inside universities, which creates opportunities for TTOs such as ISIS. A weakness in the communication between industries and government health authorities also creates need for intermediation to address negative consequences, such as misallocation of finance, or misaligned decisions, policies and legislation. Membership organisations such as SEHTA are directing resources towards servicing this gap.

Our research shows that the predominant use of informal relationships in the intermediation process raises significant governance issues. The government has recognised the need to focus on a better understanding of the market and the industry needs, and it is exploiting Interactions. Industry and Higher Education, 27(4): 263-278. 
various formal and informal communication channels through institutions such as TSB. The dependence on informal channels of communication entangles intermediaries in two-way or three-way communications, where decisions are in the hands of the personal discretion of individuals. The two-way communication channels are actively employed both by public and private sector organisations that deliver information services between government bodies and universities, or between government bodies and firms and universities, therefore affecting transparency and accountability.

Our empirical observations confirm the need of intermediaries to engage in network creation and in managing networked relationships. Such network governance (Frances, J. et al, 1991) requires new platforms of multi-lateral contracts and community governance, as well as collaborative mechanisms for forming and coordinating research consortia, co-financing of innovation activities and assistance in the context for knowledge and technology transfer. Further studies of network creation and network management are essential for the advancement of $\mathrm{TH}$ relationships.

Our four cases of intermediaries employ two-way and three-way communication channels to enable government to meet the real needs of businesses and universities. However, from a regulatory point of view, such a dual representation is a classic example of a conflict of interests which intermediaries have to manage. It is essential to conduct further research into how intermediaries manage their dual roles, conflict of interests and ethical professional conduct in their governing function.

Many intermediaries specialise in services at a specific stage of the innovation process. During the final stage (take products and services to the market) the most effective financial intermediaries are banks and investors such as venture capital firms (IPSO). During this stage Interactions. Industry and Higher Education, 27(4): 263-278. 
Technology Transfer Offices (such as ISIS) provide support and facilitate the academic side of the knowledge interaction. There is evidence that the financial and institutional intermediaries are connected with each other in order to be able to enhance the synergies across the fragmented field of R\&D interactions.

Our empirical observations indicate that dynamics within the Triple Helix system involve dynamics at sub-levels too. Every element is changing, including strategies and roles of the actors, types of interactions, types of knowledge and technology transfer, activities and operations of the intermediaries, or modalities of regulation of university-industrygovernment relationships. Meetings, briefings and events bring together policy makers with business leaders from industry and academic leaders from university, shaping future directions for the innovation process.

\section{Acknowledgements:}

The progress of this work was supported by David Parry, CEO SEHTA, UK and his facilitated sponsorship for the mapping of the GSE Health Technology Cluster, and Stefano Fior, who undertook the task of empirical testing and demonstration of the heuristics of the 'Triple Helix Intermediation' model for his Master's Thesis for Università Degli Studi di Padova, Facoltà di Ingegneria, Italy.

\section{Bibliography}

Agrawal, A. (2001) 'University-to-Industry Knowledge Transfer: Literature Review and Unanswered Questions', International Journal of Management Review, Vol 3, No 4, pp $285-302$.

Agrawal, A. and Henderson, R. (2002) 'Putting Patents in Context: Exploring Knowledge Transfer from MIT', Management Science, Vol 48, No 1, pp 44-60.

Antonelli, C. (1999) The Microeconomics of Technological Systems. Oxford University, Press. Argote, L. and Ingram, P. (2000) 'Knowledge Transfer: A Basis for Competitive Advantage in Firms', Organizational Behaviour and Human Decision Processes, Vol 82, No 1, pp 150-169. 
Bendor, J. (1990) 'Formal Models of Bureaucracy: A Review', in: Lynn, N. and Wildavsky,

A. (Eds), Public Administration: The State of the Discipline, Chatham, NJ: Chatham House, pp. 373-417.

Borsch, O. (1994) 'The Process of Relational Contracting: Developing Trust-Based Strategic Alliances Among Small Business Enterprises', Advances in Strategic Management, Vol 10, pp 113-136.

Bramwell, A., and Wolfe, D. (2008) 'Universities and Regional Economic Development: The Entrepreneurial University of Waterloo', Research Policy, Vol 37, pp 1175-1187.

Cannon, T. (1994) Corporate Responsibility: A textbook on Business Ethics, Governance, Environment: Roles and Responsibilities. Pitman, London.

Cohen, W., Nelson, R. and Walsh, J. (2002) 'Links and Impacts: the Influence of Public Research on Industrial R\&D', Management Science, Vol 48, No 1, pp 1-23.

Cowan, R., Foray, D. (1997) The Economics of Codification and Diffusion of Knowledge, MERIT, Maastricht.

Dodgson, M. and Bessant, J. (1996) Effective Innovation Policy: a New Approach. London, Thomson.

Etzkowitz, H., and Leydesdorff, L. (1995) 'The Triple Helix, University-IndustryGovernment Relations: a Laboratory for Knowledge Based Economic Development', EASST Review, Vol 14, pp 14-19.

Fior, S. (2010) 'The Role of Intermediaries in Knowledge and Technology Transfer (KTT) Activities between Universities and Industries in the UK Healthcare Sector', MSc Dissertation, Università Degli Studi di Padova, Facoltà di Ingegneria, Italy.

Fligstein, N., Freeland, R. (1995) 'Theoretical and Comparative Perspectives on Corporate Organization', Annual Review of Sociology, 21: 21- 44.

Frances, J. et. al. (1991) 'Introduction', in: Thompson, G. et. al. (Eds) Markets, Hierarchies and Networks: The Co-ordination of Social Life, Sage Publ., London.

Frenken, K. (2000) 'A Complexity Approach to Innovation Networks. The Case of the Aircraft Industry (1909-1997)', Research Policy, Vol 29, No 2, pp 257-272.

Galeotti, Andrea; Moraga-Gonzalez, Jose (2009) 'Platform Intermediation in a Market for Differentiated Products', European Economic Review, Vol 53, pp 417-428.

Gehrig, T. (1993) 'Intermediation in Search Markets', Journal of Economics and Management Strategy, Vol 2, No 1, pp 97-120.

Gu, Bin (2003) 'The Dual Effects of Third-party Information on Market Competition', University of Texas at Austin Working Paper.

3 Todeva, E. (2013). Governance of Innovation and Intermediation in The Triple Helix 3 Interactions. Industry and Higher Education, 27(4): 263-278. 
Gubeli, H. and Doloreux, D. (2005) 'An Empirical Study of University Spin-off

Development', European Journal of Innovation Management, Vol 8, No 3, pp 269-282.

Haugland, Sven (1999) 'Factors Influencing the Duration of International Buyer-Seller Relationships', Journal of Business Research, Vol 46, pp 273-280.

Hellman, T. (2005) 'The Role of Patents for Bridging the Science-to-Market Gap', NBER working paper No. 11460, Cambridge, Mass.

Hellman, T., Puri, M. (2002) 'Venture Capital and the Professionalization of Start-up Firms: Empirical Evidence), The Journal of Finance, Vol 57, No 1, pp 169-197.

Justman, M. and Teubal, M. (1996) 'Technological Infrastructure Policy (TIP): Creating Capabilities and Building Markets', in: Teubal M. et. al. (Eds), Technological Infrastructure Policy: An International Perspective, Dordrecht, Kluwer.

Lee, J. and Liu, Q. (2008) 'The Dynamics of Bargaining Postures: The Role of a Third Party', Penn Institute of Economic Research Working Paper 09-001.

Levacic, R. (1991) ‘Markets: Introduction’, in: Thompson, G. et. al, (Eds), Markets, Hierarchies and Networks: The Coordination of Social Life, Sage Publ., London.

Levy, R., Roux, P. and Wolff, S. (2009) 'An Analysis of Science-Industry Collaborative Patterns in a large European University', Journal of Technology Transfer, Vol 34, pp 1-23. Leydesdorff, L. (2001) A Sociological Theory of Communication: The Self-Organization of the Knowledge-Based Society, Parkland, FL: Universal Publishers.

Leydesdorff, L. (2006) The Knowledge-Based Economy and the Triple Helix Model. Edward Elgar.

Leydesdorff, L. and Etzkowitz, H. (1998) 'The Triple Helix as a Model for Innovation Studies', Science \& Public Policy, 25(3): 195-203.

Lissenburgh, S. and Harding, R. (2000) Knowledge Links: Innovation in University / Business Partnerships. London: IPPR.

Malerba, F., Nelson, R., Orsenigo, L. and Winter, S. (1999) “"History-Friendly” Models of Industry Evolution: The Computer Industry', Industrial and Corporate Change, Vol 8, No 1, pp 3-35.

Manzini, P., Mariotti, M. (2002) 'Arbitration and Mediation: An Economic Perspective', Institute of Labour Studies Discussion Paper No. 528, IZA, http://www.iza.org/publications/dps/.

Meyer-Krahmer, F., Schmoch, U. (1998) 'Science-based Technologies: University-Industry Interactions in Four Fields', Research Policy, Vol 27, pp 835-851. Interactions. Industry and Higher Education, 27(4): 263-278. 
Mirowski, P. and Van Horn, R. (2005) 'The Contract Research Organization and the Commercialization of Scientific Research', Social Studies of Science, Vol 35, p 503.

Monjon, S., Waelbroeck, P. (2003) 'Assessing Spillovers from Universities to Firms: Evidence from French Firm-Level Data', International Journal of Industrial Organization, Vol 21, pp 1255-1270.

Narin, F., Hamilton, K. and Olivastro, D. (1997) 'The Increasing Linkage Between U.S. Technology and Public Science', Research Policy, Vol 26, pp 317-330.

Neudorf, L. (2009) 'Judicial Independence: The Judge as a Third Party to the Dispute', PhD Thesis, Faculty of Law, Institute of Comparative Law, McGill University, Montreal.

Parkinson, J. (1994) Corporate Power and Responsibility. Oxford University Press, Oxford. Pearce, L. (2003) 'Disaster Management, Community Planning and Public Participation: How to Achieve Sustainable Hazard Mitigation', Natural Hazards, Vol 28, pp 211-228.

Robinson, D., Rip, A. and Mangematin, V. (2007) 'Technological Agglomeration and the Emergence of Clusters and Networks in Nanotechnology', Research Policy, Vol 36, No 6, pp 871-879.

Roessner, J. (1993) 'What Companies Want from the Federal Labs', Issues in Science and Technology, Vol 10, No 1, pp 37-42.

Rubinstein, A.,Wolinsky, A. (1987) 'Middlemen', The Quarterly Journal of Economics, Vol 102, No 3, pp 581-593.

Russell, G. and Waste, R. (1998) 'The Limits of Reinventing Government', American Review of Public Administration, Vol 28, No 4, pp 325-346.

Schartinger, D., Rammer, C., Fischer M. and Frohlich J. (2002) 'Knowledge Interactions Between Universities and Industry in Austria: Sectoral Patterns and Determinants', Research Policy, Vol 31, pp 303-328.

Shane, S. (2002) 'Selling University Technology: Patterns from MIT', Management Science, Vol 48, No 1, pp 122-137.

Todeva, E. (1998) 'The Transformation of the Socialist Governance System', South Bank European Papers, 6-98, London.

Todeva, E. (2005) 'Governance, Control and Co-Ordination in Network Context: The Cases of Japanese Keiretsu and Sogo Shosha', Journal of International Management, Vol. 11, pp. 87-109.

Todeva, E. (2008) Health Technology Cluster in the Greater South East, Report by SEHTA and the University of Surrey.

3 Todeva, E. (2013). Governance of Innovation and Intermediation in The Triple Helix Interactions. Industry and Higher Education, 27(4): 263-278. 
Todeva, E. 2010. Theoretical Tensions between Regulation, Governance, and Strategic Behaviour in a Federated World Order', International Journal of Social Economics, 37 (10): 784- 801.

Ohta, T., Lee, K., Kakehi, K. (2008) 'Role of Formal Boundary Spanning Structure and Changing Pattern of University-Industry Collaborative Research in University of Tokyo', PICMET 2008 Proceedings, 27-31 July, Cape Town, South Africa.

Wilson, W. (1987) ‘The Study of Administration', Political Science Quarterly, Vol 2, pp $197-$ 222.

Yusuf, S. (2008) 'Intermediating Knowledge Exchange Between Universities and Businesses', Research Policy, 37: 1167-1174.

Zucker, L., Darby, M. and Armstrong, J. (2002) 'Commercializing Knowledge: University Science, Knowledge Capture, and Firm Performance in Biotechnology', Management Science, Vol 48, No 1, pp 138-153. Interactions. Industry and Higher Education, 27(4): 263-278. 


\section{Fig. 1. Intermediation in the Triple Helix Relationships}

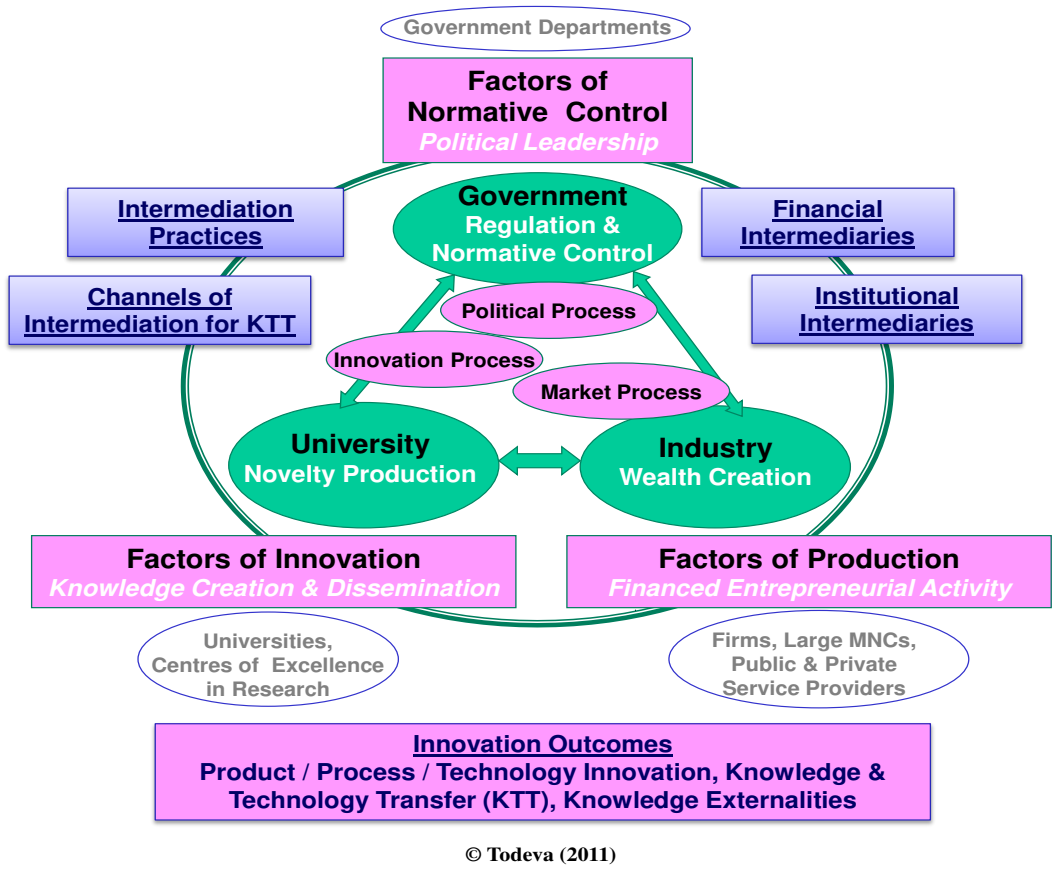

Fig. 2. Intermediation Activities and Practices for the Innovation Process

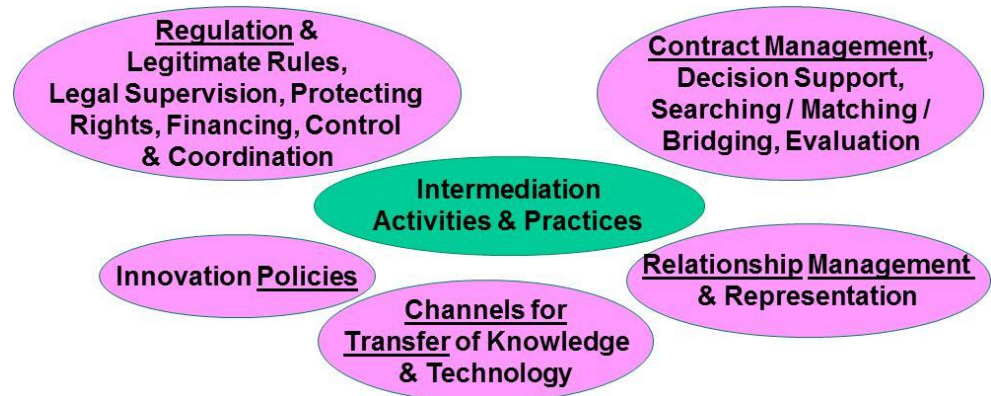

Fig. 3. Knowledge and Technology Transfer Channels

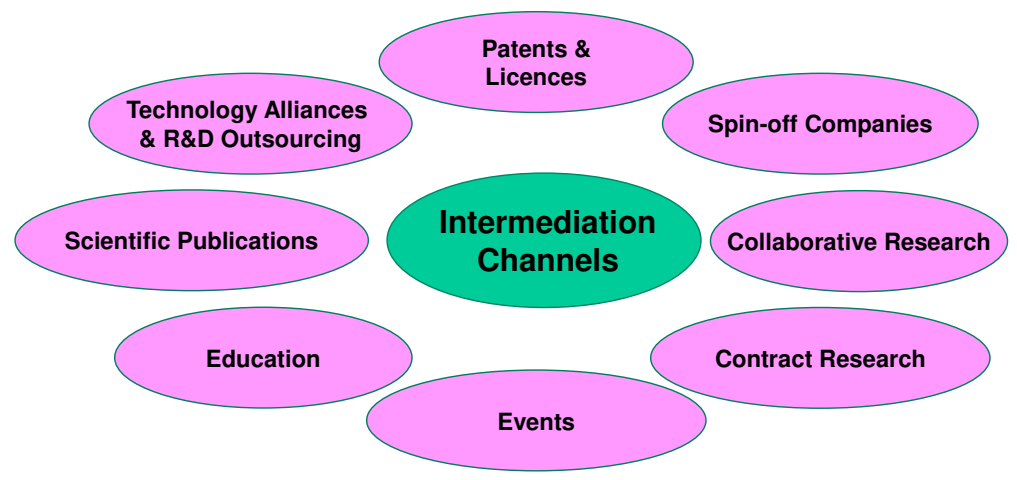

3 Todeva, E. (2013). Governance of Innovation and Intermediation in The Triple Helix Interactions. Industry and Higher Education, 27(4): 263-278. 
Table 1. Intermediaries in the Health Technology Sector in the Greater South East, UK

\begin{tabular}{|c|c|c|c|c|}
\hline & TSB & SEHTA & IPSO Ventures & ISIS Oxford \\
\hline Ownership & $\begin{array}{l}\text { Public institution (since } \\
\text { 2007) }\end{array}$ & $\begin{array}{l}\text { Company limited by } \\
\text { guarantee (since 2005) }\end{array}$ & Private company & $\begin{array}{l}\text { University company } \\
\text { (since 1988) }\end{array}$ \\
\hline Financed by & $\begin{array}{l}\text { Government: Dep. for } \\
\text { Business Innovation \& } \\
\text { Skills, other government } \\
\text { departments, Regional } \\
\text { Development Agencies \& } \\
\text { Research Councils }\end{array}$ & $\begin{array}{l}\text { Regional Development } \\
\text { Agency - SEEDA }\end{array}$ & Private Owners & University of Oxford \\
\hline $\begin{array}{l}\text { Facilitate in } \\
\text { distribution of } \\
\text { funds }\end{array}$ & From Government & From Funding bodies & $\begin{array}{l}\text { Own funds \& those } \\
\text { from private investors }\end{array}$ & From Private investors \\
\hline \multirow{5}{*}{$\begin{array}{l}\text { Main strategy } \\
\text { \& objectives }\end{array}$} & $\begin{array}{l}\text { Support business } \\
\text { development }\end{array}$ & $\begin{array}{l}\text { Provide membership } \\
\text { representation }\end{array}$ & Market pull strategy & $\begin{array}{l}\text { Balancing technology } \\
\text { push \& market pull } \\
\text { strategy }\end{array}$ \\
\hline & $\begin{array}{l}\text { Stimulate technology- } \\
\text { enabled innovation in the } \\
\text { areas of national } \\
\text { strategic importance for } \\
\text { boosting UK growth \& } \\
\text { productivity }\end{array}$ & $\begin{array}{l}\text { Support small } \\
\text { businesses in the Health } \\
\text { technology cluster in the } \\
\text { SEEDA region }\end{array}$ & $\begin{array}{l}\text { Exploit intellectual } \\
\text { property \& technology } \\
\text { developed inside } \\
\text { universities \& create } \\
\text { business opportunities }\end{array}$ & $\begin{array}{l}\text { Translate university's IP, } \\
\text { innovation products, } \\
\text { knowledge \& } \\
\text { technology into business } \\
\text { opportunities }\end{array}$ \\
\hline & $\begin{array}{l}\text { Promote, support \& } \\
\text { invest in technology } \\
\text { research }\end{array}$ & $\begin{array}{l}\text { Manage funds provided } \\
\text { by non-departmental } \\
\text { government bodies }\end{array}$ & $\begin{array}{l}\text { Translating university } \\
\text { IP into licensing \& } \\
\text { spin-out companies }\end{array}$ & $\begin{array}{l}\text { Assist in university } \\
\text { development }\end{array}$ \\
\hline & $\begin{array}{l}\text { Facilitate inter-firm } \\
\text { networking, university- } \\
\text { industry links \& } \\
\text { knowledge dissemination }\end{array}$ & $\begin{array}{l}\text { Understand business } \\
\text { needs \& market } \\
\text { landscape; Understand } \\
\text { University direction }\end{array}$ & $\begin{array}{l}\text { Understand where } \\
\text { there are new } \\
\text { business opportunities } \\
\text { \& potential demand }\end{array}$ & $\begin{array}{l}\text { Assist researchers to } \\
\text { identify \& manage } \\
\text { consulting opportunities }\end{array}$ \\
\hline & & $\begin{array}{l}\text { Promote industry } \\
\text { interests to policy } \\
\text { makers, regulators, the } \\
\text { media \& the general } \\
\text { public }\end{array}$ & $\begin{array}{l}\text { A bridge between } \\
\text { industry \& university }\end{array}$ & \\
\hline \multirow{7}{*}{$\begin{array}{l}\text { Types of } \\
\text { facilitation }\end{array}$} & $\begin{array}{l}\text { Provide funds for } \\
\text { programs \& projects }\end{array}$ & $\begin{array}{l}\text { Assist companies \& } \\
\text { universities to obtain } \\
\text { funding }\end{array}$ & $\begin{array}{l}\text { Analyse the market } \\
\text { landscape \& identify } \\
\text { business opportunities }\end{array}$ & $\begin{array}{l}\text { Contributes revenue to } \\
\text { the University of Oxford } \\
\text { from patents \& licensing }\end{array}$ \\
\hline & $\begin{array}{l}\text { Create knowledge } \\
\text { transfer networks for } \\
\text { knowledge sharing \& } \\
\text { problem solving }\end{array}$ & $\begin{array}{l}\text { Understand \& interpret } \\
\text { the policies of the main } \\
\text { funding bodies; Monitor } \\
\text { industries' needs }\end{array}$ & $\begin{array}{l}\text { Discuss business } \\
\text { opportunities with } \\
\text { potential investors }\end{array}$ & $\begin{array}{l}\text { Inform investors \& } \\
\text { professionals about the } \\
\text { latest inventions by the } \\
\text { University of Oxford \& } \\
\text { about the new business } \\
\text { opportunities }\end{array}$ \\
\hline & $\begin{array}{l}\text { Support knowledge } \\
\text { transfer partnerships \& } \\
\text { placements of graduates } \\
\text { in businesses under } \\
\text { academic leadership }\end{array}$ & $\begin{array}{l}\text { Manage a membership } \\
\text { database \& provide } \\
\text { members with better } \\
\text { orientation about the } \\
\text { innovation \& technology } \\
\text { landscape }\end{array}$ & $\begin{array}{l}\text { Develop the most } \\
\text { important ideas \& } \\
\text { inventions born inside } \\
\text { universities \& provide } \\
\text { commercial value to } \\
\text { them, so they can be } \\
\text { exploited by industries }\end{array}$ & $\begin{array}{l}\text { Identify, protect \& } \\
\text { market technologies } \\
\text { through licensing, spin- } \\
\text { out company formation, } \\
\text { consulting \& material } \\
\text { sales }\end{array}$ \\
\hline & $\begin{array}{l}\text { Facilitate links across } \\
\text { industry networks \& } \\
\text { spread knowledge }\end{array}$ & $\begin{array}{l}\text { Design \& participation in } \\
\text { collaborative research } \\
\text { projects }\end{array}$ & $\begin{array}{l}\text { Provide management } \\
\text { expertise \& human } \\
\text { capital to the newly } \\
\text { founded companies }\end{array}$ & $\begin{array}{l}\text { Negotiate exploitation \& } \\
\text { spin-out company } \\
\text { agreements }\end{array}$ \\
\hline & $\begin{array}{l}\text { Coordinate a large } \\
\text { number of partners \& } \\
\text { create a flow of } \\
\text { information between } \\
\text { them that goes in both } \\
\text { directions, both top-down } \\
\& \text { bottom-up }\end{array}$ & $\begin{array}{l}\text { Act as double } \\
\text { intermediary - informing } \\
\text { the businesses regarding } \\
\text { Government's policies, } \\
\text { funding \& market } \\
\text { legislation, \& the } \\
\text { Government about the } \\
\text { businesses situation \& } \\
\text { needs }\end{array}$ & $\begin{array}{l}\text { Help its portfolio } \\
\text { companies with } \\
\text { acquisitions, mergers, } \\
\text { collaborations \& } \\
\text { licensing opportunities }\end{array}$ & $\begin{array}{l}\text { Follows every step of } \\
\text { the spin-out process, } \\
\text { from the identification of } \\
\text { the researchers, to the } \\
\text { investors, arriving at the } \\
\text { managers, thus } \\
\text { facilitating the running of } \\
\text { the new business } \\
\text { represent all the actors } \\
\text { that contribute to the } \\
\text { business creation }\end{array}$ \\
\hline & $\begin{array}{l}\text { Assist government in } \\
\text { improving policy areas }\end{array}$ & $\begin{array}{l}\text { Circulate a newsletter \& } \\
\text { provide information to } \\
\text { industry }\end{array}$ & $\begin{array}{l}\text { Facilitate relationships } \\
\text { between universities \& } \\
\text { industries via licensing } \\
\& \text { spin-out creation }\end{array}$ & $\begin{array}{l}\text { Manage joint initiatives } \\
\text { with the NHS \& the DoH } \\
\text { in the form of research } \\
\text { hospital \& research } \\
\text { centres }\end{array}$ \\
\hline & $\begin{array}{l}\text { Facilitate understanding } \\
\text { of policy trends }\end{array}$ & $\begin{array}{l}\text { Work with life science } \\
\text { research \& development }\end{array}$ & $\begin{array}{l}\text { Exploit university } \\
\text { innovation }\end{array}$ & $\begin{array}{l}\text { Identify technology } \\
\text { development }\end{array}$ \\
\hline
\end{tabular}

3 Todeva, E. (2013). Governance of Innovation and Intermediation in The Triple Helix 


\begin{tabular}{|c|c|c|c|c|}
\hline & & establishments & & opportunities \\
\hline & $\begin{array}{l}\text { Understand business } \\
\text { needs \& market } \\
\text { landscape }\end{array}$ & $\begin{array}{l}\text { Work with the health } \\
\text { authorities in the region }\end{array}$ & & $\begin{array}{l}\text { Identify \& manage } \\
\text { consultancy } \\
\text { opportunities }\end{array}$ \\
\hline & $\begin{array}{l}\text { Maintains close } \\
\text { relationships with other } \\
\text { funding bodies, } \\
\text { professional associations } \\
\& \text { government institutions }\end{array}$ & $\begin{array}{l}\text { Work with national } \\
\text { Government bodies, } \\
\text { national associations, } \\
\text { councils, funding bodies, } \\
\text { Government \& no- } \\
\text { Government institutions }\end{array}$ & & $\begin{array}{l}\text { Manage networks of } \\
\text { university researchers \& } \\
\text { inventors, Oxford spin- } \\
\text { outs, technology transfer } \\
\text { professionals, local } \\
\text { companies \& some of } \\
\text { the world's most } \\
\text { innovative multinationals }\end{array}$ \\
\hline & & $\begin{array}{l}\text { Participate in trade } \\
\text { exhibitions, in national } \\
\text { science events, in joint } \\
\text { programmes for } \\
\text { companies focused on } \\
\text { business plan \& funding }\end{array}$ & & $\begin{array}{l}\text { Maintain close } \\
\text { relationships with all } \\
\text { funding bodies \& works } \\
\text { closely with the } \\
\text { Research services } \\
\text { department in the } \\
\text { University of Oxford }\end{array}$ \\
\hline & $\begin{array}{l}\text { Sponsor / organise } \\
\text { meetings \& events }\end{array}$ & $\begin{array}{l}\text { Organise meetings \& } \\
\text { events }\end{array}$ & & $\begin{array}{l}\text { Provide funds for patent } \\
\text { applications \& legal } \\
\text { costs }\end{array}$ \\
\hline & $\begin{array}{l}\text { Use informal } \\
\text { relationships }\end{array}$ & $\begin{array}{l}\text { Develop relationships } \\
\text { Networking \& contacts }\end{array}$ & $\begin{array}{l}\text { Networking \& creation } \\
\text { of links \& relationships }\end{array}$ & $\begin{array}{l}\text { Build a network of } \\
\text { potential investors (VCs } \\
\text { \& Business Angels) }\end{array}$ \\
\hline
\end{tabular}

Note: Developed and Adapted from Fior (2010) 